Original Article

Yam B Roka, MS, MCh

Department of Neurosurgery

Neuro Cardio and MultiSpeciality hospital

Biratnagar, Nepal

Address for correspondence:

Yam B Roka, MS, MCh

Department of Neurosurgery

Neuro Cardio and MultiSpeciality hospital

Biratnagar, Nepal

Email: dryamroka@yahoo.com

Received, 9 February, 2017

Accepted, 17 February, 2017

$\mathrm{C}$

ranioplasty is the surgical repair of cranial defect or deficiency of the skull with a aim for functional and coemetic improvement. The history of cranioplasty dates back to 3000 B.C. ${ }^{1}$ although the first documentation was done by Fallopius using gold and van Meekeren using bone graft. ${ }^{30}$ Cranioplasty materials took a leap forward during the first and second world wars where there was a great demand due to the war related injuries. Inorganic and organic materials have both been used for
Nepal Journal of Neuroscience 14:7-13, 2017

\section{Review of the History of Materials Used With Experience with Bone Cement Cranioplasty}

Cranioplasty is the surgical repair of cranial defect or deficiency of the skull with a aim for functional and cosmetic improvement. Inorganic and organic materials have both been used for cranioplasty with the ideal cranioplasty material is yet to be made or discovered with present focus of research on molecular biology. This article does a brief review of the history of materials used and discusses the results of the use of bone cement cranioplasty (BCC) in this centre. A total of 61 cases were included in the study with the majority being males (44 cases). Road traffic accident was the most common initial cause of injury (45 cases), followed by fall (10 cases) and physical assault in the rest. On admission and based on the GCS based head injury classification the majority were in the severe head injury type $(\mathrm{GCS}<8)$ in 44 cases followed by moderate head injury in the rest. The majority of the decompressive craniectomy was done on the left side (32 cases) followed by right ( 22 cases) and bilateral in 7 cases (including single flap bifrontal in 5 cases). In our centre as for other centres in Nepal and developing countries, bone cement remains the best, safest, cheapest choice along with autologous graft for cranioplasty.

Key Words: cranioplasty, bone cement, neurosurgical history

cranioplasty with no consensus as to which is the better one. ${ }^{18}$ The ideal cranioplasty material is yet to be made or discovered and the characteristics desirable are listed in Table 1. ${ }^{3}$ The present focus of research has shifted to molecular biology to regenerate the bone using the patients own tissue. Use of 3-D printers has also revolutionized the technique of cranioplasty in terms of the exact shape, anatomical curvature, cosmetic appearance and size of defect. This article does a brief review of the history of 
Roka et al

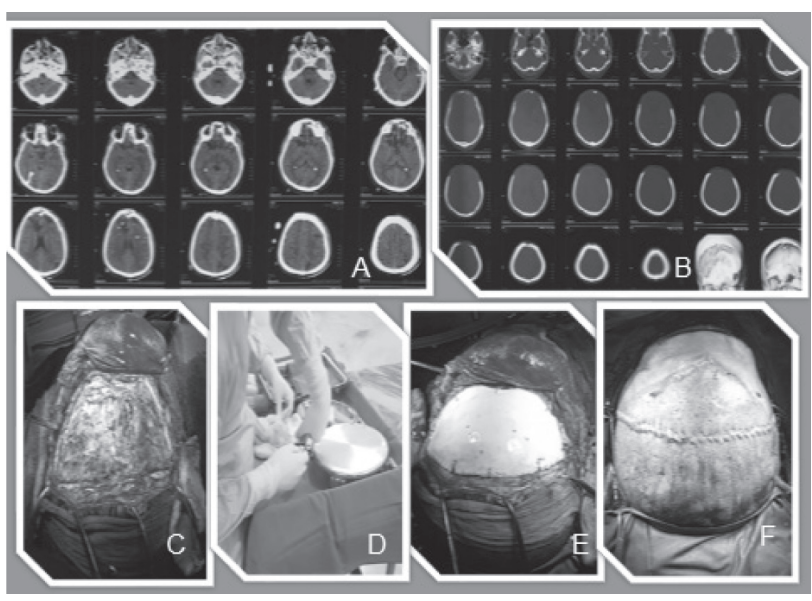

Figure 1: A) Showing the preoperative CT, B) Bi-Frontal decompressive craniectomy CT, C) Preparation of the flap, D) Mixing the bone cement, E) Completion of the BCC and fixation with non-absorbable sutures and F) closure of the wound in continuous suture

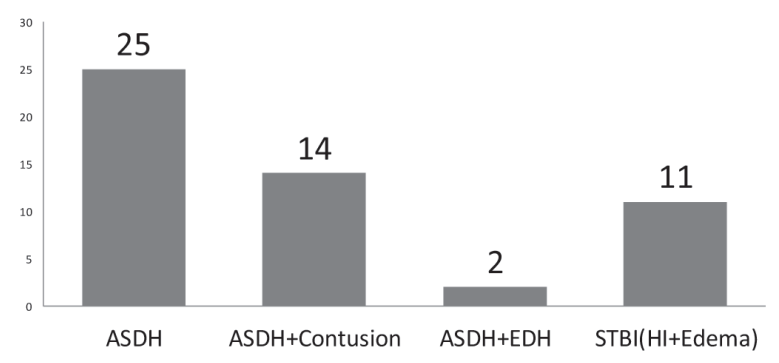

Figure 2: Showing the initial pathology in CT at admission

materials used and discusses the results of the use of bone cement cranioplasty (BCC) in this centre.

\section{Materials and Methods}

This is a retrospective study of all cases that underwent BCC in this centre from January 2010 to February 2017. The number of cases, demographical profile, cause of injury with admission GCS, duration for cranioplasty and complications are noted.

Surgical technique consisted of early repair if possible and delayed (more than year) if infection was present. Preoperative 3-D CT was done to study the intracranial and bony defect, size, shape and any other abnormalities. The decompressive defect was opened and the flap raised. Bone cement was prepared using sterile technique and molded into the shape and size of the defect. The powder was mixed with $80 \mathrm{mg}$ of Gentamycin antibiotic during preparation. The extra cement and the edges were shaped to fit the decompressive defect and ice cold water used to remove the exothermic heat during setting of the cement. . Few holes were made in the centre of the mould to avoid subflap collection. 5 holes were made with drill and the cement was fixed to hole in the parent bone correspondingly to achieve an immobile cranioplasty. The skin flap was replaced and closed in two layers with the skin in continuous non-absorable suture (Figure 1). Closed suction drain was placed for 48 hours and the sutures were removed on 14th day with follow-up at 1, 3 and 12 months.

\section{Results}

A total of 61 cases were included in the study with the majority being males (44 cases). Road traffic accident

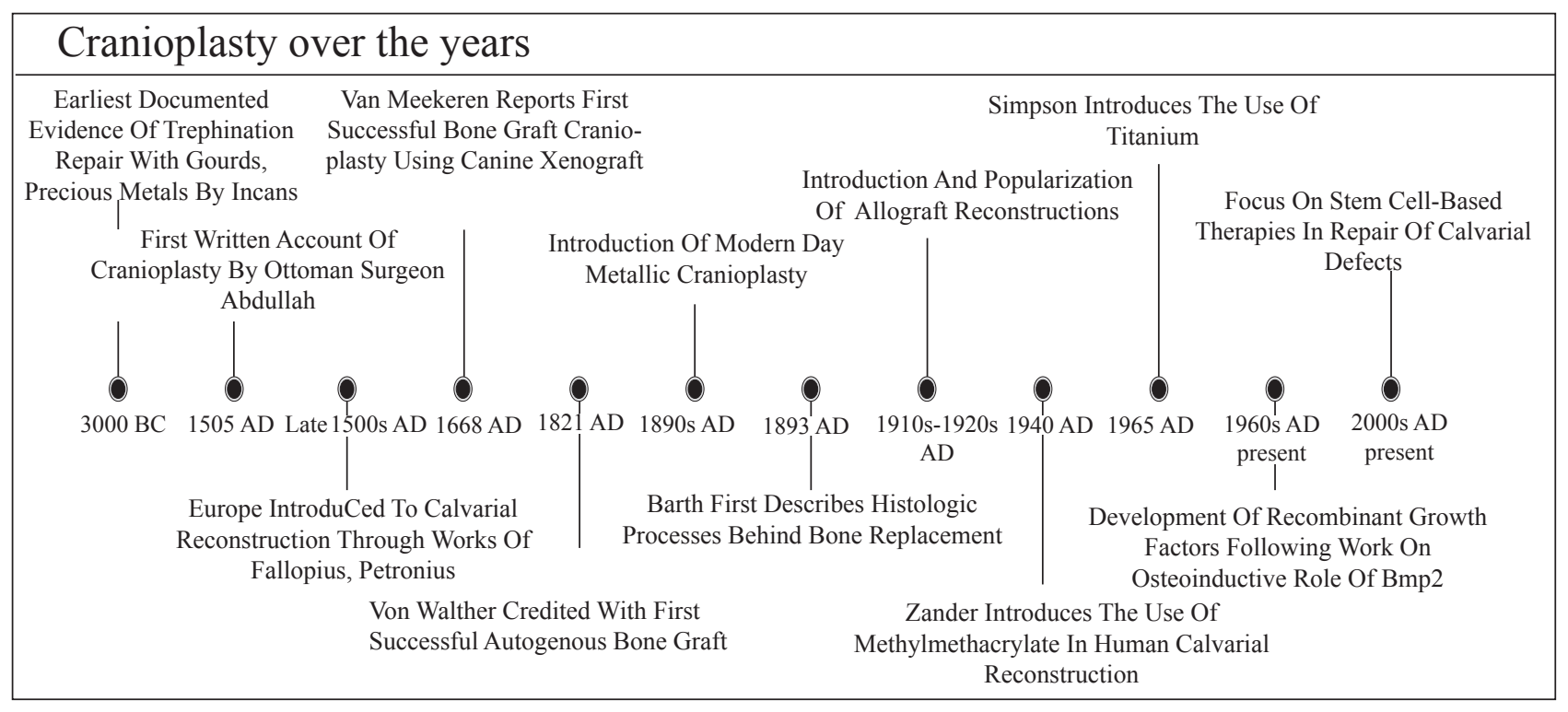

Figure 3: Timeline of the history of cranioplasty. ${ }^{9}$ 
- It must fit the cranial defect and achieve complete closure

- Not dilated with heat

- Radiolucency

- Easy to shape

- Not expensive

- Resistance to infections

- Ready to use

- Strong to biomechanical processes

Table 1: Showing the characteristics of an ideal cranioplasty material 3

\begin{tabular}{|l|l|}
\hline S. No & Complications \\
\hline & Infected Flap- 5\% \\
\hline & Hydrocephalus- 3\% \\
\hline & Subdural Hygroma- 5\% \\
\hline & Seizure- 1.6\% \\
\hline & Cosmetic - 10\% \\
\hline
\end{tabular}

Table 2: The list of complication in this study

was the most common initial cause of injury (45 cases), followed by fall (10 cases) and physical assault in the rest. On admission and based on the GCS based head injury classification the majority were in the severe head injury type $(\mathrm{GCS}<8)$ in 44 cases followed by moderate head injury in the rest. The initial pathology on CT showed acute subdural hematoma in the majority followed by diffuse head injury and cerebral edema (Figure 2). The majority of the decompressive craniectomy was done on the left side ( 32 cases) followed by right ( 22 cases) and bilateral in 7 cases (including single flap bifrontal in 5 cases). After the initial surgery the majority of the cases underwent BCC after 3 months with 15 cases undergoing within 1 month and the rest 13 cases between 1 to 3 months. There was no procedure related mortality and the morbidity was limited to infection and cosmetic complains (Table 2). Three cases of infection were initially tried with antibiotics and burr hole drainage of the collection failure of which needed removal of the BCC. A delayed cranioplasty was done in two cases after 12 months.

\section{Discussion}

Decompressive craniectomy is one of the commonest emergency neurosurgical procedures performed worldwide. Non-traumatic craniectomies are also done for infection, tumours and other causes for raised intracranial pressure. These defects are managed by cranioplasty which aims not only to cover and give a cosmetic importance but also gives a physiological and psychological relief to the patient. The earliest cranioplasties was performed by the Incas using gold, silver and gourd covers around 3000-2000 B.C. Fallopius is credited for performing the cranioplasty using a gold plate in 1523-1562 while von Meekeren was the first to utilise bone cranioplasty in 1668 (Figure 3) ${ }^{29}$ Except for the cases with local infection, brain swelling, untreated hydrocephalus, co-morbid conditions contraindicating surgery, children less than 4 years (autograft preferred), all cases can be managed with cranioplasty. Although there is a small debate as to the timing of cranioplasty numerous studies have shown no benefit of either early or delayed surgery in non-infected cases. Those with infection can be managed at no later than 6 months after control of infection (12 months in this series).

There are numerous different techniques used to cover the cranial defect including skull reconstructions with autologous, allogenic and alloplastic substitutes. Autologous bone has been harvested from the tibia, ribs, iliac and locally from the skull. Allografts are derived from cadavers whereas Xenograft are derived from animals (bovine). There are numerous artificial materials available for cranioplasty that include Methyl methacrylate, hydroxyapatite, ceramics, and polyetheretherketone (PEEK) implants (Table 3). A brief description follows of the materials used with special emphasis in bone cement for cranioplasty.

\section{Autograft Cranioplasty}

This was popularized by Ollier (1859) and Macewen (1873) with other modification in 1890 by Müller and König , the latter being the most used technique. This was superseded by the von Hacker method that utilized surrounding periosteum and outer table to cover the defect. ${ }^{13,22,26,40}$ This was followed by the use of Iliac, rib, tibia, sternum and scapula for cranioplasty. Autologous bone is the most commonly used procedure to repair the defect. The initial bone, bone fragments, bone dust or local harvested bone can be fixed in situ with help of non-absorbable sutures, titanium wires or plates and even plateless fixation devices. For longer delays the bone can be safely placed inside scalp or abdominal subcutaneous flaps. Use of Cryofreezing and bone banks has led to preservation for long durations. They can also be kept in antibiotic solutions and reused with or without autoclaving. Bone flap resorption is a major problem in delayed cranioplasties which can be dealt with early surgery or replacement by synthetic grafts.

\section{Allograft cranioplasty}

Morestin first used cadaver cartilage in 1915 because it was thought that it could resist infection although the lack of calcification was a major deterrent for further use. Cadaveric skull were also used after treatment with 
Roka et al

\begin{tabular}{|c|c|c|c|c|c|}
\hline Material type & $\begin{array}{l}\text { Used by/ } \\
\text { year }\end{array}$ & Advanatages & Disadvantages & $\begin{array}{l}\text { Present } \\
\text { status }\end{array}$ & $\begin{array}{l}\text { Reference } \\
\text { number }\end{array}$ \\
\hline $\begin{array}{l}\text { Autograft } \\
\text { Cranium } \\
\text { Tibia } \\
\text { Rib/Scapula } \\
\text { Fascia } \\
\text { Sternum/ilium }\end{array}$ & $\begin{array}{l}\text { Macewan } \\
\text { (1885) } \\
\text { Exhausen } \\
\text { Early20 }^{\text {th }} \\
\text { century } \\
\text { - }\end{array}$ & $\begin{array}{l}\text { Biocompatible,low } \\
\text { infection, easy } \\
\text {-do- } \\
\text { Biocompatible } \\
\\
\text {-do-,more viable } \\
\text { Biocompatible }\end{array}$ & $\begin{array}{l}\text { Limited size and } \\
\text { shape } \\
\text { Painful,difficult } \\
\text { Increase complication } \\
\text { Harvesting,mobilise } \\
\text { Difficult,small area, } \\
\text { inc. complications }\end{array}$ & $\begin{array}{l}\text { In small } \\
\text { defects } \\
\text { Not used } \\
\text { Not used } \\
\text { In use } \\
\text { Not used }\end{array}$ & $13,22,26,40$ \\
\hline $\begin{array}{l}\text { Metal allografts } \\
\text { Gold/Silver } \\
\text { Aluminum } \\
\text { Tantalium/lead/ } \\
\text { Vitallium/platinium } \\
\text { Titanium }\end{array}$ & $\begin{array}{l}\text { Incas } \\
20^{\text {th }} \text { century } \\
\text { WW II } \\
\\
\text { Recent years }\end{array}$ & $\begin{array}{l}\text { Easy to mould, inert } \\
\text { Cheap } \\
\text { Mouldable } \\
\text { Easy,less } \\
\text { infection, inert,MRI } \\
\text { compatible }\end{array}$ & $\begin{array}{l}\text { Cost, oxidation of } \\
\text { silver } \\
\text { Epilepsy,infection } \\
\text { Cost,infection,toxicity, } \\
\text { headache } \\
\text { Cost }\end{array}$ & $\begin{array}{l}\text { Not used } \\
\text { Not used } \\
\text { Not used } \\
\text { In Use }\end{array}$ & $13,25,37,38$ \\
\hline $\begin{array}{l}\text { Non-Metal } \\
\text { MethylMethacrylate } \\
\text { Hydroxyapatite } \\
\text { Silicon/ } \\
\text { Polyethylene } \\
\text { Cortoss }\end{array}$ & $\begin{array}{l}\text { WW } \\
\text { II,Spence } \\
1954 \\
- \\
1968\end{array}$ & $\begin{array}{l}\text { Shape, any size, cheap, } \\
\text { easy to use } \\
\text { Less reaction } \\
\text { Easy,mouldable,less } \\
\text { allergy } \\
\text { Less Infection, strong, } \\
\text { bioactive }\end{array}$ & $\begin{array}{l}\text { Infection, } \\
\text { rejection,cosmetic } \\
\text { Break easily } \\
\text { Soft } \\
\text { Cost, limited area }\end{array}$ & $\begin{array}{l}\text { In use } \\
\text { Limited use } \\
\text { Not in use } \\
\text { Limited use }\end{array}$ & $3,19,15,32,40$ \\
\hline Allograft & Early 1500 & Easy to procure, cheap & $\begin{array}{l}\text { Allergy, rejection, } \\
\text { infection }\end{array}$ & Not in use & 8,13 \\
\hline Xenograft & Early 1500 & Easy to procure, cheap & $\begin{array}{l}\text { Allergy, rejection, } \\
\text { infection }\end{array}$ & Not in use & 8 \\
\hline $\begin{array}{l}\text { ell-Based } \\
\text { Therapies, growth } \\
\text { factors }\end{array}$ & $21^{\text {st }}$ century & $\begin{array}{l}\text { Reliable, osteogenic, } \\
\text { useful in children } \\
\text { biocompatible, }\end{array}$ & $\begin{array}{l}\text { Experimental, costly, } \\
\text { smaller size }\end{array}$ & $\begin{array}{l}\text { Experimental, } \\
\text { Small defect }\end{array}$ & $16,28,34,35,36$, \\
\hline
\end{tabular}

Table 3: Showing the different types of materials used and their advantages and disadvanatages.

sodium carbonate, xylol, alcohol, and ether, followed by heat, for cranioplasty. This procedure though had high infection rates and was not used. . $^{8,13}$

\section{Xenograft cranioplasty}

Canine, ape, goose, rabbit, ox horn, buffalo and ivory have all been used for cranioplasties. The success of autograft and the increased complication have reduced the use of xenograft for cranioplasty. ${ }^{8}$

\section{Alloplasts}

\section{Metals}

Numerous metals have been used for cranioplasties that include Gold, Silver, lead, Aluminium (Booth and Gersten), Vitallium alloys by Geib (1941), Tantalum by Pudenz and Odom (1942); stainless steel by Boldrey, Scott, Wycis, and Murtagh (1944, 1956), titanium by
Simpson (1965) and Tantalum. ${ }^{10,12,13}$ Tantalum was used during World War II but due to price, limited supply, and complications from high thermal conduction, its use was discontinued shortly. ${ }^{13,25,37,38}$ The complications associated with metal implants are infection, seizure, imaging artifacts on CT scans, dislodgement, heat conduction, headache, scalp erosion or perforation, cost and lack of malleability. Titanium remains the common metal that is used today with or without bone cement. It comes in various sizes and can be shaped to fit the defect completely even in children. ${ }^{39}$ Computer generated models have greatly enhanced the cosmetic and functional outcome using titanium.

\section{Acrylics}

Acrylic was first used in animal models which showed that it adhered to the dura with no underlying reaction. Although used primarily by dentist its use was expanded 
for cranioplasty during the World War II. Acrylic is easy to shape, lighter, radiates less heat, radiolucent, cheap and easily available, giving it advantage over metals. Article of Spence in 1954 and Zander in 1940, popularized its use. ${ }^{15,32,40}$ Although the choice of many for adult cranioplasty it use is limited in children and should be avoided in less than 5 years due to its lack of osteointegration.

\section{Methyl Methacrylate}

Methyl methacrylate is a polymerized ester of acrylic acid with strength comparable to bone, strong, heat resistant, radiolucent, and inert which was discovered in 1939. The radiolucent nature could lead to angiography being done but did not show fractures for which a little amount of Barium was added. MMA comes in a powder and has to mixed with the liquid provided which forms a initial soft paste that be shaped and moulded to any size. The exothermic reaction involves use of cold water to cool down and it can be interlayered with titanium mesh. Although safe to use MMA does have few complications The exothermic reaction during preparation can lead to burn and long term complications (5-40\%) include, infection (5-20\%), fracture, scalp erosion or fistulization and hypersensitivity reactions $(1 \%) .5,7,17,11$

\section{Hydroxyapatite}

To counter the problems of shape and size adjustment and prevent artifacts on the CT scan Hydroxyapatite which is a hexagonal calcium phosphate compound found naturally in bone or synthetically manufactured as a ceramic was introduced. It can thus be used in children as there is little reaction and has good bonding with bone. It though has disadvantages like, low tensile strength, high infection, brittleness, disintegration with time and unpredictable response when exposed to blood or cerebrospinal fluid. ${ }^{14,23,33}$ Patients with hydroxyapatite must stay away from trauma till full bone is formed.

\section{Alumina ceramics}

These are newer materials used in cranioplasty which are hard as diamond, comparable tissue compatibility as acrylics, chemically stable, low post-operative infection and slightly radiopaque. The drawback being expensiveness, prone to shatter and need to be prefabricated before use. . $^{24,30}$

\section{PEEK Implants}

Polyetheretherketone (PEEK) is a semicrystalline polymer that can be sterilized by steam or gamma irradiation. PEEK is radiolucent, chemically inert, and has strength, thickness, and elasticity comparable to cortical bone. It does not create artifact on CT or
MRI, can be shaped with computer or 3-D printing, are translucent, its porous framework allows for theoretical bony ingrowth and vascularization, non-magnetic, light with no thermal conduction. They are expensive, lack osteointegrative properties, can be dislodged and has infection problems. ${ }^{319,30}$

\section{Pediatric Cranioplasty}

If the dura and pericranium are intact smaller defects in children close spontaneously. The basic principles of remain cranioplasty remain the same as for adults except for few limitations of the pediatric age group where the osteogenic potential of the cranium is inversely proportional and decreases rapidly after 1 year of age. ${ }^{31}$ Resorption of the bone is a major problem which can be delayed with use of synthetic bone or mesh. The growing skull with its contour changes places limitations on synthetic materials and thus the results of latter are not acceptable on long term follow-up. Autologous bone remains the best choice for cranioplasty and thus must be preserved for future use. Osteogaleal flaps are an alternative for reconstruction in pediatric defects due to their membranous origin, ease of harvest, reliable vascularity, and applicability to any part of the cranium. Coralline hydroxyapatite granules mixed with Avitene and autologous blood, bone substitutes that avoid rigid fixation, osteoinductive factors such as bone morphogenetic protein (BMP) for the reconstruction, autologous cranial particulate bone grafts mixed with autologous blood are some of the other ways to achieve defect closure. ${ }^{6,13}$ Before 3 years of age, the diploic space is not reliably present and the skull is thin and thus split cranial bone graftingcan be performed only after 3 years and in situ cranial bone grafting only after 9 years of age. If the scalp cannot be closed primarily then preoperative subgaleal scalp expansion, skin grafting, local or pedicle vascular roattion flaps can be used for covering the defect. Some of the common flaps used include latissimus dorsi myocutaneous flap, rectus abdominus flap, radial forearm flap, and omentum flap. ${ }^{41}$ The choice of a scalp cover is determined by the anatomy (size, depth, and axial blood supply) and physiology (radiation, infection) of the defect in addition to patient factors such as comorbidities, oncological issues, and cosmetic concerns. ${ }^{27}$

\section{The future of cranioplasty}

\section{Growth Factors}

Histological proof that transplanted bone cells die but leave scaffolding on which living bone can form, was first described by Barth (1893). Modern research focuses on ways to improve revascularization, osteoinduction to osteoconduction and osteogenesis. Osteoinduction can lead to osteoprogenitor cells that will be produced in situ 


\section{Roka et al}

with the aid of bone morphogenetic proteins, which would be infused into an implant. Use of recombinant factors such as transforming growth factor $b$, insulin-like growth factor-I, and BMP-2 and tissue engineering in augmenting calvarial closure in animal and human models are being studied. ${ }^{16,28,36}$

\section{Stem Cell-Based Therapies}

Recent advances in laboratory research have shifted the focus from osteoconduction to a more osteoinductive framework, whereby undifferentiated mesenchymal cells can be transformed into osteoprogenitor cells in situ. Stem cell-based therapies hold enormous promise in this regard, demonstrating successful repair of critical-sized cranial defects by using human induced pluripotent stem cells (iPSCs), bone marrow derived stem cells (BMSCs), and adipose-derived stem cells (ASCs) in mouse models. ASCs possess several advantages over BMSCs (possibility for malignant transformation and acquisition of foreign antigens) including rapid in vitro expansion, higher cell numbers achievable through ASC harvests and increased proliferation rates in vitro ease of harvest, and higher in vivo abundance. ${ }^{2,4,34,35,20,21}$ Although iPSCs heal cranial defects concerns including teratoma formation and insertional mutagenesis persist. These concerns must be addressed and minimized prior to the use of iPSCs in clinical trials. A timeline graph is shown in Figure 2. ${ }^{9}$

\section{Present study}

The present study has dealt with bone cement cranioplasty in a 7 year study. BCC is cheap, easily available, moldable and at affordable cost. This study has shown the good results associated with BCC with minimal or acceptable morbidity. Use of titanium mesh or plating could reduce the number of cosmetic side effects. The use of Gentamycin during preparation may be one reason for the reduced infection. There have been no cases with fracture and in cases of infection the redo-BCC was done at more than a year. In the cases of $\mathrm{BCC}$ removal even at more than 6 months there was no adhesion or neovascularization of the bone cement. Placement of a drain and smaller holes in the BCC are some ways to avoid post-operative collection.

\section{Conclusions}

Cranioplasty for skull defects is still a challenge today in spite of all the research and improvements in materials used. Literature reported complications range from $16 \%$ to $40 \%$, with a general reoperation rate of $25 \%$. An ideal cranioplasty material bearing the aforementioned characteristics is yet to be available. Use of material is often dictated by the availability, cost, age of patient, personal experience and institutional preferences. Multidisciplinary approach for complex defects is needed and hence should be done to give the best results. At present, autologous grafts, MMA, PEEK, and titanium remain the most used materials. Use of 3D printing and computer based models along with research in tissue factors will definitely change the approach to cranioplasty. In our centre as for other centres in Nepal and developing countries, bone cement remains the best, safest, cheapest choice along with autologous graft for cranioplasty.

\section{References}

1. Asenjo A: Neurosurgical Techniques. Springfield, IL: Charles C Thomas, 1963

2. Barth A: Über histologische Befunde nach Knochenimplantationen. Arch Klin Chir 46:409417, 1893

3. Blake DP. The use of synthetics in cranioplasty: A clinical review. Mil Med 159:466-9, 1994

4. Blom EJ, Klein-Nulend J, Yin L, van Waas MA, Burger EH: Transforming growth factor- $\beta 1$ incorporated in calcium phosphate cement stimulates osteotransductivity in rat calvarial bone defects. Clin Oral Implants Res 12:609-616, 2001

5. Blum KS, Schneider SJ, Rosenthal AD: Methyl methacrylate cranioplasty in children: long-term results. Pediatr Neurosurg 26:33-35, 1997

6. Choi SH, Levy ML, McComb JG: A method of cranioplasty using coralline hydroxyapatite. Pediatr Neurosurg 29:324-327, 1998

7. De Bonis P, Frassanito P, Mangiola A, Nucci CG, Anile C, Pompucci A: Cranial repair: how complicated is filling a "hole"? J Neurotrauma 29:1071-1076, 2012

8. Durand JL, Renier D, Marchac D: The history of cranioplasty. Ann Chir Plast Esthet 42:75-83, 1997 (Fr)

9. Feroze AH, Walmsley GG, Choudhri O, Lorenz HP, Grant GA, Edwards MS. Evolution of cranioplasty techniques in neurosurgery: historical review, pediatric considerations, and current trends. J Neurosurg 123:1098-107,2015

10. Gardner WJ: The use of tantalum for repair of cranial defects in infected cases. Cleve Clin Q 13:72-87, 1946

11. Gautschi OP, Schlett CL, Fournier JY, Cadosch D: Laboratory confirmed polymethyl-methacrylate (Palacos)-hypersensitivity after cranioplasty. Clin Neurol Neurosurg 112:915-916, 2010

12. Geib FW: Vitallium skull plates. JAMA 117:8-12, 1941 
13. Grant FC, Norcross NC: Repair of cranial defects by cranioplasty. Ann Surg 110:488-512, 1939

14. Grant GA, Jolley M, Ellenbogen RG, Roberts TS, Gruss JR, Loeser JD: Failure of autologous boneassisted cranioplasty following decompressive craniectomy in children and adolescents. J Neurosurg 100 (2 Suppl Pediatrics): 163-168, 2004

15. Gurdjian ES, Webster JE, Brown JC: Impression technique for reconstruction of large skull defects. Surgery 14:876-881, 1943

16. Hock JM, Centrella M, Canalis E: Insulin-like growth factor I has independent effects on bone matrix formation and cell replication. Endocrinology 122:254-260, 1988

17. Jaberi J, Gambrell K, Tiwana P, Madden C, Finn R: Longterm clinical outcome analysis of poly-methylmethacrylate cranioplasty for large skull defects. J Oral Maxillofac Surg 71:e81-e88, 2013

18. Khader BA, Towler MR. Materials and techniques used in cranioplasty fixation: A review. Mater Sci Eng C Mater Biol Appl 66:315-22, 2016

19. Lethaus B, Safi Y, ter Laak-Poort M, KlossBrandstätter A, Banki F, Robbenmenke C, et al: Cranioplasty with customized titanium and PEEK implants in a mechanical stress model. J Neurotrauma 29:1077-1083, 2012

20. Levi B, Hyun JS, Montoro DT, Lo DD, Chan CK, Hu $\mathrm{S}$, et al: In vivo directed differentiation of pluripotent stem cells for skeletal regeneration. Proc Natl Acad Sci U S A 109:20379-20384, 2012

21. Levi B, James AW, Nelson ER, Vistnes D, Wu B, Lee $M$, et al: Human adipose derived stromal cells heal critical size mouse calvarial defects. PLoS ONE 5:e11177, 2010

22. Macewen $\mathrm{W}$ : An address on the surgery of the brain and spinal cord. Br Med J 2:302-309, 1888

23. Martini L, Staffa G, Giavaresi G, Salamanna F, Parrilli A, Serchi E, et al: Long-term results following cranial hydroxyapatite prosthesis implantation in a large skull defect model. Plast Reconstr Surg 129:625e-635e, 2012

24. Matsuno A, Tanaka H, Iwamuro H, Takanashi S, Miyawaki S, Nakashima M, et al: Analyses of the factors influencing bone graft infection after delayed cranioplasty. Acta Neurochir (Wien) 148:535-540, 2006

25. Mayfield FH, Levitch LA: Repair of cranial defects with tantalum. Am J Surg 67:319-332, 1945

26. Müller P: Deckung von schädeldefekten aus dem sternum. Zentralbl Chir 23:409-410, 1915

27. Mulliken JB, Glowacki J, Kaban LB, Folkman J,
Cranioplasty

Murray JE: Use of demineralized allogeneic bone implants for the correction of maxillocraniofacial deformities. Ann Surg 194:366-372, 1981

28. Reddi AH: Morphogenesis and tissue engineering of bone and cartilage: inductive signals, stem cells, and biomimetic biomaterials. Tissue Eng 6:351-359, 2000

29. Sanan A, Haines SJ: Repairing holes in the head: a history of cranioplasty. Neurosurgery 40:588-603, 1997

30. Shah AM, Jung H, Skirboll S. Materials used in cranioplasty: a history and analysis. Neurosurg Focus 36:E19,2014

31. Shonka DC Jr, Potash AE, Jameson MJ, Funk GF: Successful reconstruction of scalp and skull defects: lessons learned from a large series. Laryngoscope 121:2305-2312, 2011

32. Spence WT: Form-fitting plastic cranioplasty. J Neurosurg 11:219-225, 1954

33. Teixeira S, Fernandes H, Leusink A, van Blitterswijk C, Ferraz MP, Monteiro FJ, et al: In vivo evaluation of highly macroporous ceramic scaffolds for bone tissue engineering. J Biomed Mater Res A 93:567575,2010

34. ThesleffT, LehtimäkiK, Niskakangas T, Mannerström B, Miettinen S, Suuronen R, et al: Cranioplasty with adiposederived stem cells and biomaterial: a novel method for cranial reconstruction. Neurosurgery 68:1535-1540, 2011

35. Urist MR: Bone: formation by autoinduction. Science 150: 893-899, 1965

36. Verheggen R, Merten HA: Correction of skull defects using hydroxyapatite cement (HAC)-evidence derived from animal experiments and clinical experience. Acta Neurochir (Wien) 143:919-926, 2001

37. White JC: Late complications following cranioplasty with alloplastic plates. Ann Surg 128:743-754, 1948

38. Wollaston WH: On the identity of columbium and tantalum. Philos Trans R Soc Lond 99:246-252, 1809

39. Woodhall B, Spurling RG: Tantalum cranioplasty for war wounds of the skull. Ann Surg 121:649-668, 1945

40. Woolf JI, Walker AE: Cranioplasty: collective review. Int Abstr Surg 81:1-23, 1945

41. Yamada H, Sakai N, Takada M, Ando T, Kagawa $\mathrm{Y}$ :Cranioplasty utilizing a preserved autogenous bone flapcoated with acrylic resin. Acta Neurochir (Wien) 52:273-280, 1980 